\title{
EKONOMSKE POLITIKE U RAZVOJU EKONOMSKE NAUKE
}

\section{REZIME}

Ekonomska politika predstavlja sistem međusobno povezanih ekonomskih procesa putem koji se nastoji uspešno upravljati tržištem. Sistem ekonomskih procesa mora biti fleksibilan kako bi se prilagođavao promenama na tržištu usled kriza i drugih poremećaja. Da bi ekonomska politika mogla da funkcioniše ekonomija mora biti tržišno orijentisana kako bi se moglo empirijski pristupiti odnosu među učesnicima na tom tržištu. Prošlost u razvoju ekonomske nauke predstavlja vrlo bitan segment u njenom razvoju, jer se na osnovu nje razume sadašnjost razvoja ekonomske nauke, a određuju smernice za daljni razvoj ekonomske nauke u budućnosti. Iz tog se može izvući i složenost ekonomske nauke, imajući u vidu da je tokom prošlosti u njenom razvoju dolazilo do mnogobrojnih promena ekonomskih politika u različitim vremenskim periodima kada je svetsko tržište pratio i određeni društveno-ekonomski razvoj.

Ta složenost se posebno ispoljava kod ekonomskih politika koje su zagovarale aktivnosti države u razvoju ekonomije s jedne strane i ekonomskih politika koje su zagovarale potpuno liberalno tržište bez bilo čijih delovanja s druge strane. Tadašnje ekonomske politike su pobijale i negirale ideje i zagovaranja drugih ekonomskih politika sve do pojave Hicks- Samuelsonove teze. ${ }^{4}$

Ključne reči: ekonomska politika, ekonomska nauka, neoliberalizam, kenzijanizam.

\section{UVOD}

Značaj ekonomiji kao nauci pridaje se krajem XVIII i početkom XIX veka u periodu rapidnog razvoja tada novog društvenog sistema, kapitalizma. Taj period poznat po naglom razvoju proizvodnje $\mathrm{i}$ procvatu tržišta, sa sobom je nosio i turbulentna dešavanja na tržištu koja su stvarala mogućnosti za pojavu kriza. Logično je bilo da su se tada aktivnosti od strane tadašnjih ekonomista znatno iskazivale kada su u pitanju ekonomske pojave na tržištu. Normalno je bilo da se mnogi ekonomisti nisu slagali i nisu imali jedinstvena stajališta kada je u pitanju objašnjenje za nastale ekonomske pojave i njihove uzroke, pa je ujedno to i dovodilo do različitih ekonomskih politika u razvoju ekonomske nauke. $U$ to vreme značaj razvoju ekonomije kao nauke se pridavao na način što se nastojalo doći do načina kako da država poveća svoje bogatstvo. Da bi razumeli ekonomiju kao nauku, a time razumeli i kretanja, te turbulencije koje se javljaju na tržištu, potrebno je da razumemo njen istorijski razvoj od prvih njenih početaka. Naime, od tih prvih početaka kroz sam razvoj ekonomije kao nauke prolazile su brojne ekonomske politike i njihove teorije koje su bitno uticale na razvoj ekonomije. Ekonomske politike u razvoju ekonomska nauke se definišu kao različita sagledavanja ekonomske realnosti i kao različito promatranje, objašnjenje i rešenje problema u onim vremenskim periodima u kojima se nastali problem tretira. U praksi retko nailazimo na slučajeve gde ekonomska politika ne utiče na ponašanje privrednika na tržištu. U kojoj meri i kako ekonomska politika utiče na ponašanje privrednika, uglavnom ovisi o strukturi ekonomske politike, periodu njenog delovanja, te spremnosti vlasti za njihovu primenu. ${ }^{5}$

Tako dakle, nakon odredenog privrednog procvata na svetskim tržištima ravnoteža na tim tržištima se nije mogla napraviti pa je početkom 30-tih godina XX veka u svetu došlo do velike ekonomske krize koja je ostavila velike posledice po svetsku privredu. Te posledice su se iskazale kroz nagli rast nezaposlenosti, pad industrijske proizvodnje, pad cena poljoprivrednih proizvoda, itd. Pojava krize je ukazala da tada primenjivane ekonomske politike su imale svoje određene nedostatke, te je bilo potrebno izvršiti i odredene prepravke. prošlosti. 6

Kako u svojim delima navodi J.K.Galbraith, ekonomiju je nemoguće razumeti bez svesti o njenoj

\footnotetext{
'Svetlana Ignjatijević, Docent, Fakultet za ekonomiju I inženjerski menadžment u Novom Sadu, Novi Sad, e -mail: svetlana.ignjatijevic@gmail.com

${ }^{2}$ Hidroelektrana Trebinje, BiH

${ }^{3}$ Vojna akademija, Beograd

${ }^{4}$ Hicks-Samuelsonova teza-teza koja integriše kejnzijansku makroekonomiju i klasičnu mikroekonomiju.

${ }^{5}$ B.Golić, Principi ekonomije, Pravni fakultet, Sarajevo,2002, str. 66.

6 Ibidem, str. 66.
} 
Tada se javlja britanski ekonomista John Maynard Keyns sa svojom novom politikom koja će dobiti ime po njemu, kejnsijanska politika tj. kejnsijanizam. Kejnsijanska politika smatra da neoklasični mehanizmi nisu rešenje kada je u pitanju potpuna zaposlenost, gde zbog nepotpune zaposlenosti država mora da interveniše na način što će povećati svoju potrošnju i tako umanjiti pad nastao kao posledica smanjenja zaposlenosti. Naime, zaposleni radnici koji su radili su imali odredena primanja koje su trošili i namirivali svoje potrebe. Kada su ostali bez posla ostali su i bez svojih primanja i tako nisu bili u mogućnosti da nastave sa potrošnjom i kupovinom određenih roba za svoje potrebe. Sa smanjenjem kupovne moći tih radnika automatski se i smanjila prodaja roba, a time su se smanjili i prihodi tih fabrika usled pada proizvodnje kao posledica pada potražnje. Taj pad proizvodnje u fabrikama je neminovno dovodio da još većeg pada zaposlenosti jer se radnici u tim fabrikama dobijali otkaze usled smanjenog obima posla. Upravo iz tog razlog Kejns je smatrao da je država ta koja u tim situacijama treba da deluje i da poveća svoju ličnu potrošnju kroz javne radove te na taj način gore navedeni ciklus kretanja a koji je imao trend smanjenja i pada preokrene i usmeri ga ka trendu povećanja i rasta.

Nakon nekoliko godina, tačnije 50 -tih godina XX veka kao odgovor na kejnsijansku politiku tj. kejnsijanizam rađa se jedna druga, nova ekonomske politike na čelu sa Miltonom Friedmanom koja novac stavljala na prvo mesto pa je zbog toga dobila naziv monetaristička politika, tj. monetarizam. Monetaristička politika smatra da državna intervencija nije rešenje za suzbijanje nastalih kriza te da ona dovodi do rasta svih cena.

U periodu 70-tih godina XX veka kada je na vlast došao Ronald Regan kao predsednik SAD-a, vodeće svetske sile, Margareth Thacher kao premerke Velike Britanije takođe jedne među vodećim svetskim silama u svetu, te nckoliko prvih čelnih ljudi drugih svetskih velesila, stvorila se ideja o potpuno otvorenom tržištu, tržištu koje će se samoregulisati. Oni su smatrali da tržištu treba dati značajnu slobodu u funkcionisanju. Ta ekonomska politika kojoj se pridavala značajna tržišna sloboda se zove neoliberalizam i predstavljalo je ponovno rađanje liberalizma kojeg je u svoje vreme zagovarao Adam Smith.

Osnivač monetarizma i nobelovac M. Friedman je napisao kako postoji široka saglasnost oko ciljeva ekonomske politike: visoka zaposlenost, stabilne cene, brzi rast. Manja saglasnost postoji oko toga u kojoj meri su ovi ciljevi medusobno usklađeni, a najmanja saglasnost postoji oko pitanja uloge koju pojedini instrumenti mogu i treba da imaju u postizanju tih različitih ciljeva. Suprotstavljanje inflaciji u savremenom svetu postalo je ključni faktor diferenciranja različitih koncepcija ekonomskih politika kejnsijanaca, monetarista, strukturalista7, iako je kejnsijanizam jednom prevaziđen monetarizmom, a drugi put prevaziden teorijom Supply Side Economics, a treći put ili je prevaziđen monetarizmom ili je integrisan i njim. ${ }^{8}$

\section{NEOLIBERALZAM KAO EKONOMSKA POLITIKA}

Krize 70-tih godina XX veka koje šu nastale usled naglog rasta ciena nafte su dovele do pojave stagflacije ${ }^{9}$, nakon čega je kejnsijanska politika naišla na veliku osudu i nesposobnost u vođenju stabilne ekonomije. Neoliberalizam kao ekonomska politika javlja se 70 -tih godina XX veka. $U$ to vreme je buktio vijetnamski rat usled kojeg se tržište SAD-a suočavalo sa inflacijom te deficitom u plaćanju i trgovini.

Dok je tržiste SAD-a usled vijetnamskog rata doživljavalo deficit, ostale zemlje se oporavljaju i tako postaju direktna konkurencija tržištu SAD-a. Osnovni generator kapitalizma kao društvenoekonomskog sistema jeste profit koji je glavni sinonim multinacionalnih kompanija koje imaju primarni zadatak, a to je stvaranje brzog profita. U realizaciji tog zadatka multinacionalne kompanije razvijenih zemalja 70 -tih godina XX veka nailaze na brojne prepreke kako na strani ponude tako i na strani potražnje koje predstavljaju osnovu u stvaranju ravnoteže na tržištu. Da bi se rešio nastali problem pristupilo se brojnim reformama kako bi se globalni proizvođači približili globalnim potrošačima. Karakter globalnog proizvođača su dobili na osnovu rapidnog razvoja u tehnologiji proizvodnje. Sa osudom kejnsijanizma odmah su se oglasili brojni njihovi kritičari koji su otvorili pitanje za stvaranjem neke nove ekonomske politike koja će privrede mnogih zemalja nastojati izvući iz nastalih kriza.

Neoliberalizam koji se uglavnom oslanja na ideju Washingtonskog konsenzusa ${ }^{10}$ i ideje globalizacije predstavlja reinkarnaciju liberalizma kojeg su zagovarali klasičari poput A.Smitha i ostalih.

\footnotetext{
7 J.Huston Mc Culloch, Money and inflation, a monetarist approach, Academic press, N.York, 1982, str.63-65, vidi - D.Ž.Marković, B.B.Ilić, S.Komazec, Ž.L.Ristić, D.D.Radovanović, Globalna ekonomija i geofinansije, EtnoStil, Beograd, 2011, str. 254.

8 R.C.Fair, An analisys of the assigacy of four macroecronometric models, Journal of Political Economy, 1979, i M.H.Peston, Whatever happend to macroeconomies?, Manchester University press, Manchester, 1980.

${ }^{9}$ Stagflaclja-stanje privrede u kojem istovremeno vlada i stagnacija i inflacija, tj.nagli rast i cena inezaposlenosti.

10 Washingtonski konsenzus je ime za 10 neoliberalnih ekonomskih predloga, koji su predloženi 1989. godine i koje su SAD, Kanada, Latinska Amerika i evropske zemlje provodile zadnjih 20 godina. Reč je o 1. Budžetskoj disciplini, 2.Usmeravanju državne potrošnje od podrške ekonomskim granama prema širokoj bazi mera za ekonomski porast i podršku siromašnom stanovništvu, 3.Poreznoj reformi čiji cilj je snižavanje poreza, 4.Kreditnim stopama usmerenim kako bi podržavale privredu, 5.Kompetitivnom deviznom kursu, 6.Trgovačkoj liberalizaciji to jest ukidanju ili velikom smanjivanju poreza i carina na uvoz, 7.Liberalizaciji stranih investicija, 8.Privatizaciji državnih kompanija i usluga, 9.Deregulaciji to jest ukidanju raznih zakona i drugih mera koje ograničavaju
} 
Tadašnji državnici vodećih svetskih velesila zagovaraju neolibealizam kao novu ekonomsku politiku koju uspešno sprovode na globalnom nivou pomoću svetskih finansijskih institucija IMF, WB koji sprovode neoliberalnu politiku zasnovanu na Washingtonskom konsenzusu. Tu se u prvom redu misli na Ronalda Reagana predsednika SAD-a i Margareth Thacher predsednicu vlade Velike Britanije.

Osnovna svrha Washingtonskog konsenzusa jeste adaptacija globalnoj ekonomiji i politici SAD-a. Ta adaptacija bi bila potpomognuta od strane svetskih finansijskih institucija. Pravac u kojem je usmeren Washingtonski konsenzus usmeren je uglavnom na tržišne reforme, a to se uglavnom odnosilo na reforme u makroekonomskom sektoru, oblasti fiskalne politike, usmerenost prema globalnoj ekonomiji u prvom redu prema liberalnoj trgovini i direktnim stranim ulaganjima. Te reforme na samom početku Washingtonskog konsenzusa su bile lokalnog karaktera i usmerene samo za oporavak zemalja latinske Amerike od tadašnjih kriza, međutim, vremenom će te reforme dobiti globalni karakter i biće upotrebljivane za oporavak svetske ekonomije. Pojavom finansijskih kriza krajem XX veka koje su se proširile i na zemlje istoka, Washingtonski konsenzus je iz razloga što je imao karakter tržišnog reformisanja naišao na osude i brojne kritike. Te kritike su uglavnom usmeravane na zapostavljanje razvoja institucija, jer su smatrali da je glavni pokazatelj razvoja neke zemlje upravo razvijenost njenih institucija, tj. što su institucije razvijenije to su razvijenije j njihove zemlje.

Ostale kritike su upućivane na nepoštenu raspodelu u kojima su zapostavljene siromašnije grupe kojima se ne može omogućiti pristup sredstvima kako bi se izvukli iz siromaštva. Krutost centralnoplanskih privreda i sve veći troškovi socijalne države davali su povoda za liberalnu kritiku državne privrede i socijalne politike.

Nove tehnologije unele su u privredne strukture više fleksibilnosti i brži proces prilagođavanja i tehnološkog napretka, koji su bili pogodniji uslovi za tržišnu organizaciju od tradicionalnih industrijskih kompleksa. ${ }^{11}$ Neoliberalizam kao ekonomska politika se temelji na potpunoj slobodi tržišta. Prema Friedrichu A. Hayeku koji se smatra glavnim idejnim tvorcem neoliberalizma, sloboda je "stanje u kojem jedan čovek nije podvrgnut samovoljnoj prinudi drugog ili drugih". ${ }^{12}$

Pojedini ekonomski teoretičari smatraju da neoliberalizam u principu predstavlja zadnju fazu ekonornske globalizacije i kapitalizma kao društvenog sistema. Oni naime smatraju da neoliberalizam za cilj ima ponovno uspostavljanje klasne nadmoći u kojoj će se bogati i dalje bogatiti na račun siromašnih dok će siromašni i dalje ostati siromašni. Uzimajući u obzir činjenicu da poznate svetske finansijske institucije kao što su Međunarodni monetarni fond i Svetska banka zagovaraju sniženje poreza za kompanije i bogatu elitu, a s druge strane istovremeno zagovaraju i smanjenje prava radnika, smanjenja njihovih plata, te socijalnih prava, onda možemo verovati u navedeni cilj. Kada se govori o siromašenju država koje su već siromašne, u prilog toj tezi ide i činjenica što se siromašne zemlje finansiraju preko MMF-a i zbog tog finansiranja su prisiljene da veći deo svog novca moraju usmeriti na vraćanje duga umesto da taj novac usmeravaju na svoj razvoj. Veoma loše iskustvo kada je u pitanju neoliberalna politika, doživela je Argentina koja je zbog preporuka od strane MMF-a doživela bankrot 2001. godine.

Ideje koje zagovara neoliberalizam kao ekonomska politika je još krajem drugog svetskog rata zagovarao F.A.Hayek u svom delu "Put u ropstvo" u kojem on nastoji da upozori na opasnosti koje vrebaju u socijalizmu i totalitarizmu, i gde on još tada razvija teoriju samoregulacije tržišta. Neoliberalizam kao ekonomska politika u principu nastoji da ukloni sve prepreke koje se nalaze na putu ka stvaranju otvorenog tržišta u kapitalističkom sistemu. Neoliberalisti zagovaraju minimalno uplitanje države na tržište. Bez obzira što je neoliberalizam kao ekonomska politka veliki zagovarač nemešanja države u tržište, ipak država ima određeni uticaj na tržište. Taj uticaj se ogleda na način što država putem svog pravnog sistema obezbeđuje zaštitu tržištu. Neoliberalizam kao ekonomska politika posebno dolazi do izražaja dolaskom na vlast Ronalda Reagana i Margareth Tacher, pored njih još od poznatih svetskih državnika koji su zagovarali neoliberalizam su Gerhard Schroeder, Toni Blair, Pinochet.

Karakteristika neoliberalizma je da bogati postaju bogatiji dok siromašni postaju siromašniji. Još jedna od karakteristika neoliberalizma je težnja za ekspanzijom tržišta i njihovim intenziviranjem. Neolberalizam svojom politikom nastoji da ujedini svetsku ekonomiju na osnovu slobodnog tržišta bez kontrole kapitala. Poznate svetske finansijske institucije koje funkcionišu po principu neoliberalizma su međunarodni monetarni fond, svetska trgovinska organizacija, svetska banka. Sporazumom iz Mastrihta 1991. godine neoliberalizam kao ekonomska politka je i službeno u okviru institucija EU prihvaćen u Evropskoj Uniji. Neoliberalizam kao što je već rečeno princip samoregulišućeg trzišta vidi kao najefikasniji način funkcionisanja tržišta. Međutim, u stvarnim prilikama na tržištu to samoregulisanje se moglo sprovesti samo do jedne određene granice, te se nikako nije moglo potpuno sprovesti. S druge strane politika neoliberalizma je bila nepravedna prema različitim stranama. Tu se treba opet podsetiti prethodno pisanih tekstova u kojima se govori o tome kako su bolje prolazile bogatije zemlje za koje su važila jedna pravila, a kako su lošije prolazile siromašnije zemlje za koje su vredila druga pravila. Neoliberalizam kao

tržišnu utakmicu, 10.Zakonskoj zaštiti vlasničkih prava.

11 J.Gray, Lažna zora, Masmedia, Zagreb,2002.

12 Friedrich A. Hayek, Poredak slobode, Izdanje Global book, Novi Sad, 1999, str.19, vidi - G.Tomka, Neoliberalizam - doktrina savremenog sveta, Privredna izgradnja 3-4, 2004, str. 220. 
ekonomsku politiku karakteriše redukovanje radničkih prava u cilju većeg profita, smanjenje javne potrošnje i socijalne sigurnosti, privatizacija društvenog vlasništva u privatno vlasništvo, deregulacija poslovnih propisa i liberalizacija tržišta.

Poslednja četvrta karakteristika tj. deragulacija je u principu i jedan od uzročnika poremećaja na tržištu, jer s obzirom da je "deregulacija" ona samim tim nešto već dereguliše što je regulisano i na taj način stabilizovano od poremećaja na tržištu. Ta deregulacija omogućuje određene malverizacije na tržištu koje uglavnom se vrše u korist bogatih (država, kompanija, lica, itd), a na štetu siromašnih. To još jednom potvrđuje tezu da neoliberalizam igra nepravednu igru prema različitim stranama. Prema Bradfordu DaLongu, profesoru Berkley Univerziteta principi neoliberalizma je da se maksimalno ograničiti uplitanje države u ekonomiju, da postoji velika mogućnost za razvoj zemalja van jezgre svetske ekonomije, da je globalna i čvrsto povczana ekonomija koja se odlikuje brzim i uspiješnim razvojem. ${ }^{13}$

Profesor Bradford DaLong je imao i svoja mišljenja u vezi navedenih principa. Kad je u pitanju maksimalno ograničavanje uplitanja drzave u ekonomiju, B. DeLong na osnovu iskustva zemalja koje su primenjivale kejnsijansku politiku koja im je proizvela inflaciju, zaključuje da su vlade tih zemalja krajem 70-tih godina XX veka iz socijaldemokratije se pretvorile u diktatorske vlade, nacionalizacija je minimizirala efikasnost, a maksimizirala korupciju. Kad je u pitanju postojanje mogućnosti za razvoj zemalja koje se nalaze van centra svetske ekonomije, zemlje u razvoju tj. zemlje koje se nalaze van centra svetske ekonomije primenjujući savremenu tehnologiju mogu da ubrzaju svoj razvoj tako što će skratiti tranzicioni put svog razvoja. Iste te zemlje u razvoju mogu se učiti na pozitivnim primerima koje su imale razvijene zemlje tokom svog razvoja kao i ispravljati negativne primere razvijenih zemalja. Investitori iz razvijenih zemalja u interesu svog profita imaju volju i mogućnosti za ulaganja u te zemlje u razvoju. Kad je u pitanju karakteristika globalne ekonomije, a to je brz i uspešan razvoj, B. DeLong smatra da visok nivo kretanja kapitala može delovati na razvoj zernalja u razvoju tj. zemalja koje se nalaze van centra svetske ekonomije, kao štoje slučaj Indonezije. ${ }^{14}$

Liberalizacija tržišta takođe igra ulogu koja ide u korist razvijenim zemljema za razliku od nerazvijenih zemalja. Posledica privatizacije kao jedne od karakteristika neoliberalizma jeste da se bogate privatna lica i slabi državna ekonomija na način da se sa domaćeg tržišta ispumpava novac i prenosi u strana tržišta. Iz navedenih konstatacija može se zaključiti da je neoliberalizam kao ekonomska politika kada je u pitanju ekonomija potpuno nedelotvoran. Potvrdu činjenici da je neoliberalizam neravnopravan prema različitim stranama daje podatak da su tokom vladavine neoliberalizma plate radnika uglavnom stagnirale, dok su profiti kapitalista enormno rasli.

Upozorenje tome je dao Alan Greenspan direktor američkog FED-a koji je u januaru 2008. godine rekao: "...očekivao sam i još uvek očekujem da će doći do normalizacije u raspodeli profita i plata" jer je "udeo plata u dodanoj vrednosti na najnižem niovu u istoriji, dok se $s$ druge strane produktivnost stalno poboljšava". Taj "jaz između slabog porasta plata i najvišeg profita kompanija u istoriji povećava strah i odbojnosti, u Sjedinjenim Državama kao i drugde, prema kapitalizmu i tržištu". ${ }^{15}$

Stagniranje plata tokom neoliberalizma opet dovodi do smanjenja kupovne moći čijim smanjenjem dolazi do smanjenja potražnje, čijim smanjenjem potražnje dolazi do smanjenja proizvodnje. Smanjenje proizvodnje dovodi do krize na tržištu. Na kraju može se zaključiti da neoliberalizam predstavlja doktrinu koja se bazira na moći svetskih sila upotrebljenoj na ostalim državama sveta.

\section{KEJNZIJANIZAM KAO EKONOMSKA POLITIKA}

Kejnsijanizam kao ekonomska politika predstavlja makroekonomsku politiku baziranu na idejama britanskog ekonomiste Johna Maynarda Keynsa. Kejnsijanci negiraju baziranje na privatni sektor nacionalne ekonomije i oni smatraju da takva politika može dovesti do neželjenih makrokonomskih efekata. S druge strane kejnsijanci smatraju da je javni sektor u stanju da promeni i onemogući stvaranje tih neželjenih makroekonomskih efekata i da pomoću monetarne i fiskalne politike aktivira proizvodnju. John Maynard Keyns je sve te svoje teorije prikazao u svom delu "Opšta teorija zaposlenosti, kamate i novca" 1936. godine koje će ostaviti dubok trag u proučavanju ekonomije kao nauke kako od strane njegovih kritičara tako i od strane njegovih pristalica.

Nemački ekonomist Werner Ehrilicher je kejnsijanizam kao ekonomsku politiku okarakterisao kroz četiri fundamentalne teze: Vrednost novca je determinisana makroekonomski (s obzirom da iz akumuliranih promena pojedinačnih cena koje nisu nastale monetarno, proizilaze promene opšteg nivoa cena; Nominalna novčana masa je uglavnom određena endogeno, a ne egzogeno (gde je snabdevanje privrede novcem vrlo elastično); Tendencijska nestabilnost prati potražnju privrednog sektora (zato što

\footnotetext{
13 Brad DeLong, Principles of Neoliberalism, 1999, www.j-bradford-delong.net. vidi - G.Tomkg, Neoliberalizam - doktrina savremenog sveta, Privredna izgradnja 3-4, 2004, str. 218-219.

${ }_{14}$ Ibidem, str.218-219.

${ }^{15}$ A.Greenspan, ,Le monde diplomatique, 2008.
} 
mehanizmi multiplikacije i akceleracije prate egzogene impulse); Nivo proizvodnje i zaposlenosti je makroekonomski determinisan. ${ }^{16}$

Kejnsijanska ekonomska politika ustvari podržava privatni sektor ali uz veliku dominaciju države i javnog sektora. Osnovni zadatak J.M.Keynsa je bio da u svom delu "Opšta teorija zaposlenosti, kamate i novca" utvrdi osnovne uzroke koji dovode do kratkoročnih promena u zaposlenosti, proizvodnji i dohotku. On je između ostalog udario prve temelje makroekonomiji kao vrste ekonomske discipline, dao veliku važnost izjednačavanju državnih bilansa, te povratio izgubljeno poverenje u kapitalistički sistem. Doprinos J.M.Keynsa razvoju ekonomije kao nauke ogleda se kroz: prelazak sa mikroanalize na makroanalizu; prelazak sa kratkog roka na dugi rok; prelazak sa monetarnih agregata na realne agregate; prelazak sa cenovnih varijacija na količinske varijacije; hipotezi o agregatnoj potrošnji i štednji kao stabilnim funkcijama dohotka; razdvojenosti štednje i investieija koje se mogu uravnotežiti samo promenama dohotka; tumačenju potražnje za novcem pomoću špekulativnog i transakcionog motiva; određenosti nivoa realnih nadnica obimom zaposlenosti.

Prema B. Snowdon, H. Vane, kejnsijanska ekonomska politika smatra privredu nestabilnom i podložnom dejstvu negativnih faktora kao posljedica promena granične efikasnosti investicija u odnosu na preduzetnikova očekivanja; ukoliko je privreda prepuštena samoj sebi neophodan je dug vremenski period za njenu rahabilitaciju; nivo ukupne potražnje određuje nivo ukupnog dohotka i ukupne zaposlenosti; država prvenstveno na tržište treba da deluje fiskalnom politikom u odnosu na monetarnu politiku iz razloga što je fiskalna politika efikasnija. ${ }^{17}$

Osnovni princip na kojem počiva kejnsova teorija jeste da niska kamatna stopa novac usmerava u investicije, a isto tako osigurava visoku profitnu stopu, dok je od presudne važnosti pozitivna razlika između profitne stope i kamatne stope. Kejnsijanizam je na svetskoj ekonomskoj sceni dominirao od kraja velike ekonomske depresije 1932. godine pa sve do 70-tih godina XX veka kada je usled naftnih kriza na svetskom tržištu se pojavila stagflacija za koju je okrivljena kejnsijanska ekonomska politika. Kejnsijanska politika nastoji da fiskalnom politikom stimuliše zapošljavanje. Kejnsijanci se uglavnom baziraju na fiskalnu politiku jer smatraju da fiskalnom politikom mogu da onemoguće špekulacije u vreme privrednog rasta. Međutim, oni isto tako smatraju da monetrna i fiskalna politika moraju biti u ekvilibrijumu kako bi efikasno delovali na tržište.

Kejnsijanizam kao ekonomska teorija monetarnu politiku ne smatra neutralnom tako da njenom ekspanzijom i delujući na tržišnu kamatnu stopu se stvaraju multiplicirajući efekti koji se prenose na realni sektor. Razvoj kejnsijanizma pratila je visoka deflacija koja se nije mogla sanirati već dogovrenim niskim cenama, zatim visoka nezaposlenost gde je smanjenje nadnica delovalo na smanjenje kupovne moći, nizak BDP i na kraju niska tržišna kamatna stopa.

Polazeći od čuvene izjave Johna Maynarda Keynsa da "U ekonorni ji dug rok ne postoji, na dug rok svi smo mrtvi", kejnsijanska ekonomska politika se bazira na kratkoročnim merama ekonomske politike. ${ }^{18}$

U kejnsijanskoj ekonomskoj politici efektivnom agregatnom potražnjom na koju deluje monetarna i fiskalna politika usled tendencijske nestabilnosli potražnje privatnog sektora, se makroekonomski određuje zaposlenost i proizvodnja. ${ }^{19}$

Kejns je u svojim radovima iznosio svoja mišljenja da se kapitalizam praćen visokom stopom nezaposlenosti i praćen krizama nemože zdravo razvijati. Da bi se rešio problem kriza i velike stope nezaposlenosti, Kejns je rešenje problema video u državi koja bi svojom potrošnjom i svojim rashodima potakla tada nedovoljnu potražnju. Budući da kejnsova teorija pridaje velik značaj državi, stav Kejnsa prema državi jeste da država treba da odredi ukupan iznos izvora namenjenih rastu sredstava za proizvodnju kao i visinu nagrade njihovim vlasnicima. Kao faktor smanjenja potražnje, Kejns je video u psihološkom faktoru ljudi koji su usled prevelike štednje smanjivali rast potrošnje u odnosu na rast njihovog dohotka, te investicija koje u najvećoj meri ovise o kamatnim stopama.

Rešenje problema prevelike štednje Kejns je vidio u povećanoj potrošnji od strane bogatih ljudi, dok je rešenje problema investiranja video u smanjenju realnih dnevnica, a kamatnu stopu bi regulisao eskontnom stopom. Kapitalisti uglavnom špekulišu i štede na svojim visokim dohotcima, dok radnici veći deo svojih niskih dohodaka potroše. Kejnsijanska ekonomska teorija daje minimalnu ulogu novcu i monetarnoj politici, ona odbacuje Sajov zakon tržišta i punu zaposlenost, dok pridaje značaj intervencionističkoj ekonomskoj politici. Sejov zakon tržišta se našao na udaru kritike od strane Kejnsa i ostalih kejnsijanaca zato što oni nevaže za razvijene kapitalističke privrede iz razloga što novac igra samostalnu ulogu, masa novca u opticaju ne određuje nivo cena na tržištu, a štednja ne mora da znači i nove investicije.

\footnotetext{
${ }^{16}$ D.Ž.Marković, B.B.Ilić, S.Komazec, Ž.L.Ristić, D.D.Radovanović, Globalna ekonomija i geofinansije, EtnoStil, Beograd, 2011, str. 249.

${ }^{17}$ B. Snowdon, H. Vane, Modern macrocenomics, Edvarda Elgar, 2005.

${ }^{18}$ R. Grgić, menadžment javnih finansija, Panevropski univeryitet Apeiron, 2010, str. 10.

${ }^{19}$ D.Ž.Marković, B.B.Ilić, S.Komazec, Ž.L.Ristić, D.D.Radovanović, Globalna ekonomija i geofinansije, EtnoStil, Beograd, 2011, str. 252.
} 
Međutim, globalna ekonomska kriza 2007. godine je otvorila pitanje ponovnog povratka kejnsijanske ekonomske politike na scenu iz razloga što su se mnoge zemlje pa i one koje su bile veliki kritičari i protivnici kejnsijanske ekonomske politike, a pristalice neoliberalne ekonomske politke, u cilju zaustavljanja novonastale krize pribegli merama koje zagovara kejnsijanska ekonomska politika. Dolaskom na scenu Johna Maynarda Keynesa (1883. - 1946.) i objavom njegovog poznatog dela "Opšta teorija zaposlenosti, kamata i novca" kojeg je objavio daleke 1936. godine, kada je prvi put prekinuta dominacija zakona ponude na scenu stupa makroekonomska politika. Kejnsijanska ekonomska politika se prvenstveno bavi proučavanjem potražnje na tržištu gde bi se putem fiskalne politike uticalo na povećanje zaposlenosti i privredni rast. Kejnsijanci smatraju da kamata ukoliko je i suviše niska neće uticati na investicije, nego će biti predmetom špekulacija, kao i cena nadnica koja ukoliko nema tendenciju pada neće moći obezbediti rast stope zaposlenosti.

Oni nadalje smatraju da plate i cene nisu uslovljene ponudom i potražnjom, već da su plate utvrđene diskrecijskim troškovima dok su cena utvrđene mark-upom.20

Kejnsijanska ekonomska škola ohuhvata: kejnsovu teoriju i politiku, stare kejnsijance i fiskalizam, tj. njihov model raspodele nacionalnog dohotka i potrošnje (income-expenditure model), post-kejnsijansku ekonomiju, i novu kejnsijansku ekonomiku.21

Postkejnsijanci smatraju da ekonomske teorije moraju imati značajne elemente koji će upućivati na funkcionisanje ekonomije, da su pojedinci pod uticajem institucija koje imaju svoj vlastiti sistem funkcionisanja i koji nemaju razumevanja za ograničenja i nesavršenosti. Postkejnsijanska ekonomska politika dinamiku privrednog rasta shvata kao neravnotežni proces, a ne proces kretanja iz jedne ravnoteže u drugu ravnotežu. Novac je prema njima izazvan unutrašnjim uticajem, a ne spoljnim i njega nesmatraju neutralnim ni u dugom roku niti u kratkom roku, dok raspodela dohotka je uslovljena stopom ekonomske ekspanzije. Krucijalni stavovi na kojim počiva postkejnsijanska ekonomska politika je apsolutno negiranje sledećih stavova: da je novac apsolutno neutralan i zamenjljiv za sve robe, da se apsolutno sve može zameniti tj. razmeniti za sve robe, da događaji koji će uslediti mogu uočiti analizom verovatnoće.

Kao odgovor na kritike koje je kejnsijanska ekonomska politika pretrpela 80 -tih godina XX veka, pojavljuje se "nova kejnsijanska ekonomija". Te kritike su se odnosile uglavnom na nepostojanje mikroekonomskih temelja za kejnsijanske makroekonomske teorije i politike. Nova kejnsijanska ekonomija prihvata stavove kejnsijanaca kada je u pitanju nezaposlenost ali istovremeno prihvata i kritičke stavove upućene kejnsijanskoj ekonomskoj politici. Sa tim ujedinjenim stavovima nova kejnsijanska ekonomija nastoji rešiti problem na osnovu analize uzorka i ličnih tržišnih propusta i na taj način opravdati državnu intervenciju. Uglavnom se baziraju na krutost cena i najamnina koje nastaju used razumnog ponašanja privrednih subjekata koji analiziraju česte promene cena i najamnina. Naime, oni tu krutost cena dovode u blisku vezu sa nesavršenošću konkurencije. Oni smatraju da tržišta koja imaju savršenu konkurenciju ne mogu davati mesta krutim cenama, jer na tim tržištima preduzeća moraju biti spremna da svoje cene prilagođavaju uslovima nastalim na tržištu.

Postkejnsijanska ekonomija predstavlja reinkarnaciju kejnsove ekonomske škole, sa i daljnjim nepobitnim stajalištem da se liberalna konkurencija bazira na neobjektivnim pretpostavkama. Glavno žarište njihovog istraživanja su država i privredni subjekti na tržištu u uslovima neizvesnosti. Predstavnici postkejnsijanske ekonomije su ekonomisti poljskog porekla Mihal Kalecki (1883-1970) koji je do zaključaka do kojih je dolazio Kejns u svoje vreme, dolazio na sasvim drukčiji i jednostavniji način. Nikola Kaldor (1908-1986) ekonornist mađarskog porekla, suosnivač poznatog Cambridge modela rasta22, kao i Džoana Robinson (1903-1983) ekonomista engleskog porekla ujedno i suosnivačica sa Nikolom Kaldorom, Cambridge modela rasta koji pridaje značaj raspodeli dohotka.

\section{MONETARIZAM KAO EKONOMSKA POLITIKA}

Krajem 40-tih i početkom 50-tih godina XX veka, na ekonomsku scenu stupa nova ekonomska politika zvana monetarizam čiji je osnivač i ideolog bio Milton Friedman rođen 1912. godine, profesor Univerziteta u Chicagu. Osnovna ideologija monetarizma kao ekonomske politike je stavljanje akcenta na monetarnu politiku.

Pored Miltona Friedmana, posebno se ističe i Thomas Mayer koji je prvi obrazložio i definisao strukturu monetarizma koja se po njemu sastoji od sledećih postavki: kvantitativne teorije novca; monetarističkog modela procesa transmisije; gledišta da je privatni sektor u suštini stabilan; irelevantnosti pojedinačnih pojava za objašnjenje kratkoročnih promena nominalnog dohotka i uverenje da je tržište kapitalno fluidno; stavljanje težišta na opšti nivo cijena, ne na pojedinačne cene; korištenje malih, a ne velikih ekonometrijskih modela; korišćenje iznosa primarnog novca, ili neke slične mere, kao pokazatelja

\footnotetext{
${ }^{20}$ Mark-up-razlika između ukupnog troška i prodajne cene neke robe ili usluge. Mark-up je ustvari marža.

${ }^{21}$ F. Jašarević, Z.Jašarević, Politička ekonomija, Inerlinea, Sarajevo, 2010.

22 Cambridge modela rasta- klasična podela na kapitaliste koji zarađuju profit i kontrolišu stopu investicija, te na radnike koji zarađuju platu i kontrolišu stopu potrošnje.
} 
monetarne politike; korišćenje novčane mase kao najpovoljnijeg cilja monetarne politike; usvajanje pravila o stopi rasta novčane mase; negiranje mogućnosti izbora između nezaposlenosti i inflacije i prihvatanje realne filipsove krive; pridavanje relativno većeg značaja inflaciji nego nezaposlenosti u poređenju sa ostalim ekonomistima; neslaganje sa vladinom intervencijom. ${ }^{23}$

Monetarizam se može definisati kao pravac u razvoju ekonomske nauke koji se uglavnom bazira na oživljavanju uloge monetarne politike, te na friedmanovoj kvantitativnoj teoriji novca koja kaže da svako povećanje ponude tj. mase novca na tržištu uzrokuju povećanje potrošnje na tom istom tržištu koje na kraju deluje na rast cena u kratkom roku. Monetarizam koji se bazira na novcu kao osnovnim sredstvom pomoću kojeg se utvrđuje stopa inflacije se može definisati i kao skup stajališta kojima se utvrđuje nacionalni dohodak te monetarna ekonomija. Monetarizam se također može definisati kao ekonomska politika kojom se analizira makroekonomsko delovanje ponude novca i centralnih banaka na tržište, on istražuje uzroke nastanka krize u privredi kao posledice poremećaja u monetarnom sektoru. Monetarizam pored kejnsijanizma i neoliberalizma predstavlja jednu od tri najistaknutije ekonomske politike u razvoju ekonomske nauka XX veka.

Monetarizam kao ekonomska politika s jedne strane odnosi se na istraživanje uticaja novčanog faktora na ponašanje privredne konjukture, i u tom pogledu Samuelson ${ }^{24}$ je izjavio sledeće: "Uprkos shvatanju mnogih savremenih ekonomista (i nekim mojim ranijim pogledima) smatram da monetarna i kreditna politika sadrže ogromne potencijalne mogućnosti za stimulisanje stabilizacije kao i otklanjanje depresivnih uticaja u savremenoj ekonomiji". 25

S druge strane, monetarizam kao ekonomska politika odnosi se na delovanje novca na razvoj inflacije u internoj i eksternoj ekonomiji, kao i vraćanja građanske teorije na neoliberalne koncepte u razvoju privrede i ekonomske politike. ${ }^{26}$

U svom razvoju monetarizam kao ekonomska politika beleži 5 etapa, i to: prva etapa, 50 -te godine XX veka definisanjem teorije stabilne tražnje za novcem i teorije stalnog dohotka; druga etapa, 60te godine XX veka stavljanjem akcenta na model optimalne količine novca i monetarnoj politici u monetarnoj istoriji; treća etapa, 1967. godine uvođenjem stope nezaposlenosti i prilagodljivih inflacionih očekivanja, čime je izvršen udar na kejnsovu teoriju philipsove krive; četvrta etapa, 1973.godine s prevlašću monetarizma u svim institucijama na zapadu; i poslednja peta faza, krajem 60-tih i tokom 70-tih godina XX veka se razvija negde paralelno sa četvrtom fazom, pojavom tzv. novog monetarizma. ${ }^{27}$

Jedinstvena su gledišta mnogih ekonomista koji tvrde da je monetarizam nastao krajem 50 -tih godina XX veka kao odgovor na dotada vladajuću ekonomsku politiku, kejnsijanizam. S obzirom da je monetarizam nastao kao odgovor kejnsijanizmu, pri proučavanju monetarizma od velikog je značaja poznavanje kejnsijanske ekonomske teorije. Naime, monetaristička ekonomska teorija u svom radu ima potpuno suprotna stajališta kejnsijanskoj ekonomskoj teoriji. Kejnsijanska teorija smatra da novac nije važan, dok monetarsitička teorija novac stavlja na prvo mesto. Monetarizam za razliku od kejnsijanizma odbacuje philipsovu krivu u dugom roku, negira potrebu davanja prednosti likvidnosti, uvodi čvrstu funkciju tražnje za novcem, i preferira pravila u odnosu na diskreciju.

Monetarizam ima mišljenje da na razvoj privrede krucijalnu ulogu ima opskrbljenost tržišta novcem, gde u zavisnosti od količine novca na tržištu zavisi smena privrednih ciklusa na tržištu. Monetaristi smatraju da kada bi se na tržištu količina novca povećavala i smanjivala u odnosu na smanjenje i povećanje proizvodnje i potrošnje tj.u zavisnosti od promena na tržištu, da u tom slučaju ne bi dolazilo i nebi se stvarali uslovi za nastanak kriza. Monetaristi kao i klasični teoretičari smatraju da je količina novca glavni faktor kada je u pitanju agregatna potražnja za robama i uslugama. $\mathrm{S}$ tim u vezi monetarizam predstavlja povratak klasičnoj teoriji.

Monetaristi smatraju da je kejnsijanski model koristan prikaz kratkoročnih efekata akcija monetarne politike. To znači da kratkoročna predvidanja monetarista izgledaju kejnsijanski, dok dugoročna predviđanja izgledaju klasično.28

Moentarizam se uglavnom zalagao za vladu čija bi delovanja bila ograničena i uglavnom bi se odnosila na zaštitu zakona, unutrašnje i spoljne sigurnosti, zaštitu ugovora privatnog vlasništva te zaštitu konkurentskog tržišta. Monetaristi smatraju da delovanje vlade treba da bude decentralizovano tj. raspršeno, jer snažne vlade kako su tada u stanju da prave pozitivne efekte u stanju su da prave i negativne efekte. Prema monetarnoj ekonomskoj politici Smithova tzv. nevidljiva ruka je puno efikasnija

\footnotetext{
${ }^{23}$ T:Mayer, The structure of monetarism, kredit and capital, No.2, 1975, str. 190-218, i No.3, 1975, str. 293-316, T.Mayer i drugi, The structure of monetarism, W.W.Norton \& CO, N.York, 1978, i D.Tucker, Mayer s tet of Keynsiansim: A Correction, Journal of Political Economy, 1965, str. 394-395, vidi - D.Ž.Marković, B.B Ilić, S.Komazec, Ž.L.Ristić, D.D.Radovanović, Globalna ekonomija i geofinansije, EtnoStil, Beograd, 2011, str. 199-200.

${ }^{24}$ P.A.Samuelson,:Reflections on central banking review, 1973, str.15, vidi - S.Komazec, Ž.Ristić, Makroekonomija, Etno Stil, Beograd, 2009, str. 181.

25 Ibidem.

${ }^{26}$ H. Johnson, Money, trade and economic growty, Cambrige, 1962, vidi - S. Komazes, Ž. Ristić, Makroekonomija, Etno Stil, Beograd, 2009., str. 181.

${ }_{27}$ B. Dimitrijević, Monetarizam - teorija i ekonomska politika, str. 2.

${ }^{28}$ M.Babić, Makroekonomija, Mate, Zagreb, 2007, str. 632.
} 
od kejnsijanske državne intervencije jer država treba da deluje u cilju privatnog interesa i ličnih vrednosti. Oni nadalje smatraju da prevelika državna intervencija, prevelika fiskalna politika, te prevelika socijalna pomoć imaju negativan utjecaj na privatnu svojinu i na alokaciju ograničenih resursa. Monetaristi smatraju da je glavni uzrok krize 70-tih godina na kojoj je pala kejnsijanska ekonomska politika pre svega prekomerna uloga države koju je favorizirao kejnsijanizam, zatim eskalacija novčane mase što je uzrok pojave inflacije, ekspanzija budžetskih programa, i deficit samog bužeta. Čikaška škola predstavlja glavnog pokretača kontrarevolucije prema kejnzijanizmu kao ekonomskoj politici i institucionalizma kada je u pitanju ekonomska metodologija.

Osnovna načela monetarizma kao ekonomske politike su: Monetarizam kao ekonomska politika predstavlja naslednika Sajove i Smithove doktrine ekonomskog liberalizma; monetarizam kao ekonomska politika se bazira na stabilnom i dugoročnom upravljanju ponudom novca; monetarizam kao ekonomska politika predstavlja savršeniju kvantitativnu teoriju novca definisana kao stabilnija funkcija potražnje novca; monetarizam kao ekonomska politika je politika liberalno-konzervativne desnice kod koje pojedinac nastoji da izvuče što veću korist; monetarizani kao ekonomska politika akcenat stavlja na konkretnom utvrđivanju dešavanja putem ekonomskih modela.

Monetarizam veruje u stabilnost privrede koja se nalazi u privatnom vlasništvu, pridaju značaj Sajovom zakonu29 tržišta i veruju u totalnu konkurenciju kao i u promenjljivost cena.

Fiskalnu politiku monetaristi smatraju neefikasnom iz razloga što ona opstruira investicije privatnog sektora dok s druge strane potiče inflaciju na tržištu za koju smatraju da je i krucijalni problem nestabilnosti tržišta. Osnovni zadatak monetarista jeste da svojim dejstvom povećaju konkurentnost tržišta rada, a istovremeno da smanje troškove i zaposlenih i nezaposlenih. Uloga monetarizma kao ekonomske teorije jeste da utvrdi uzročno posledične veze u monetarnoj oblasti, da utvrdi delovanje novca na stvaranje povoljne poslovne klime na tržištu kao i stvaranje negativnih posledica na tržištu kao što je inflacija.

Gledište monetarizma kao ekonomske politike su sledeća: da se monetarna pravila ili već određeni ciljevi vode na dugi rok; da je privatni sektor stabilan; da se privredni sistem nakon privrednih poremećaja automatski vraća u stanje pune zaposlenosti dok nezaposlenost se vraća na svoj prirodan nivo; na dugi rok kojeg zagovara monetarizam, promena stope monetarnog rasta koja prvenstveno deluje na promenu stope ekonomskog rasta, nestaje, dok samo ostaje stalna promena stope inflacije; kada se govori o stopi monetarnog rasta, svaka njena promena je u skladu sa stopom pune zaposlenosti, samo se menja nivo inflacije. Monetaristi smatraju da između stope rasta nominalnog dohotka, stope privrednog rasta i mase novca postoji kompatibilan odnos. Oni smatraju da sa svakim rastom mase novca će da raste i nominalni dohodak.

Monetaristi za razliku od kejnsijanaca koji zagovaraju kratkoročne mere ekonomske politike, zagovaraju dugoročne mere ekonomske poltike iz razloga što kratkoročne ekonomske politike mogu dovesti do poremećaja u dugom roku. Monetarizam kao ekonomska politika predstavlja savremenu verziju neoklasične ekonomske škole. Kad je u pitanju politika deviznog kursa, monetaristi se zalažu za politiku fleksibilnog deviznog kursa iz razloga što kod plivajućeg deviznog kursa monetarna politika ima krucifalnu ulogu.

\section{ZAKLJUČAK}

Razvoj ekonomskih politika je doveo do podele na dve grupe ekonomskih politika potpuno suprotstavljenih mišljenja čija je glavna okosnica postojanje ili nepostojanje samoregulisajućeg sistema: Prva grupa u razvoju ekonomske politike se drži čisto tradicionalnog klasičnog sistema ekonomije. Taj razvoj je išao od klasične i neoklasične ekonomije XIX i XX veka preko monetarizma do nove klasične ekonomske politike; Dok je druga grupa u razvoju ekonomske politike započela kejnsovom ekonomskom politikom u vreme velike ekonomske depresije 30 -tih godina XX veka do današnjih novih kejnsijanaca.

\section{LITERATURA}

1. B.Golić, Principi ekonomije, Pravni fakultet, Sarajevo,2002,

2. J.Huston Mc Culloch, Money and inflation, a monetarist approach, Academic press, N.York, 1982

\footnotetext{
${ }^{29}$ Sayov zakon smatra da „ponuda stvara svoju vlastitu tražnju". Taj zakon kojeg je 1803. god. predložio francuski ekonomist J.B. Say smatra, da je prekomerna proizvodnja nemoguca po svojoj prirodi. On se oslanja na gledište da ne postoji bitna razlika izmedu monetarne ekonomije i ekonomije trampe, da radnici mogu kupiti što god fabrike mogu proizvesti. Pojedini ljudi prema klasičarima, na raznim tržištima pojavljuju Se jednom kao prodavaci jedne vrste robe, a drugi put kao kupci druge vrste robe. Tako se robe razmenjuju za robu, a ljudi i njihov novac kojim plaćaju robe su posrednici koji olakšavaju razmenu. Vlasnici faktora proizvodnje dobijaju dohotke iz kojih se formira tražnja za robama. Ako je ponuda veca od tražnje, cene padaju i obrnuto, tj. ako je tražnja veca od ponude cene rastu, tako da pojava viška neprodane robe, u dužem razdoblju, nije moguća.
} 
3. R.C.Fair, An analisys of the assigacy of four macroecronometric models, Journal of Political Economy, 1979

4. D.Ž.Marković, B.B.llić, S.Komazec, Ž.L.Ristić, D.D.Radovanović, Globalna ekonomija i geofinansije, EtnoStil, Beograd, 2011,

5. M.H.Peston, Whatever happend to macroeconomies?, Manchester University press, Manchester, 1980.

6. R.C.Fair, An analisys of the assigacy of four macroecronometric models, Journal of Political Economy, 1979

7. B. Snowdon, H. Vane, Modern macrocenomics, Edvarda Elgar, 2005

8. R.Grgić, menadžment javnih finansija, Panevropski univeryitet Apeiron, 2010

\section{ABSTRACT}

Economic policy is a system of interconnected economic processes through which seeks to manage the market. The system of economic processes must be flexible in order to accommodate the changes in the market due to the crisis and other disorders. That economic policy could not function economies must be market-oriented in order to access the empirical relationship between the participants in that market. Past the development of economic science is a very important element in its development, because it is based on the present course of development of economic science, and set out the guidelines for further development of economic science in the future. From this it can extract and complexity of economic sciences, bearing in mind that in the past in its development came to the numerous changes in economic policy in different periods of time when the world market followed by a certain socio-economic development.

This complexity is especially evident in economic policy that advocated involvement of the state in economic development on the one hand and economic policy that advocated a fully liberal market without anyone's action on the other. Then economic policies are challenged and denied the idea and promoting other economic policies until the advent Hicks Samuelson's thesis.

Keywords: economic policy, economics, neoliberalism, Keynesianism. 